\title{
MAKNA GRAMATIKAL DAN LEKSIKAL UNGKAPAN \\ BAHASA BATAK SIMALUNGUN PADA UPACARA ADAT PERNIKAHAN
}

\author{
${ }^{1}$ ismi Chairani Sartika Husnul, ${ }^{2}$ imelda Amelia Gultom, ${ }^{3}$ puteri Hermalia, ${ }^{4}$ frinawaty Lestari Barus \\ 1. Universitas Negeri Medan \\ 2. Universitas Negeri Medan \\ 3. Universitas Negeri Medan \\ 4. Universitas Negeri Medan \\ 1 ismichairani15@Gmail.Com, : ' ${ }^{2}$ imeldaameliagultom @Gmail.Com, ${ }^{3}$ phermalia2@Gmai.Com, ${ }^{4}$ frinabarus@Unimed.Ac.Id
}

\begin{abstract}
Abstrak. Penelitian ini bertujuan mendeskripsikan dan menjelaskan ; 1.mendeskripsikan makna leksikan dalam pemakaian ungkapan bahasa batak simalungun pada upacara adat pernikahan, 2.mendeskripsikan makna gramatikal dalam pemakaian bahasa batak simalungun pada upacara adat pernikahan. Ini adalah penelitian kualitatif. Tehnik pengumpulan Data yang digunakan dalam penelitian ini melalui proses pengamatan data tertulis dengan catatan dan mengaplikasi metode wawancara untuk data lisan. Sumber lisan berasal dari penutur secara langsung yang didengarpenulis dalam konteks tertentu yang berbeda-beda. Umumnya bahasa yang dipakai pentutur dalam konteks tersebut adalah bahasa simalungun. Konteks yang dimakusd adalah situasi dalam berbagai kesempatan misalnya; acara dipesta dan percakapan tidak formal. Analisis data untuk melihat adatidaknya makna didalam ungkapan penutur, penulis juga membaca data tulisan yaitu buku-buku yang berisi percakapan bahasa Simalungun. Tujuan dari metode ini adalah untuk menganalisi makna gramatikal dan leksikal oemakaian ungkapan bahasa batak simalungun padaupacara pesta adat pernikahan.

Kata Kunci : Makna Gramatikal dan Leksikal, Bahasa

Simalungun
\end{abstract}

\begin{abstract}
This study aims to describe and explain; 1.describe the meaning of lexicon in the use of the expression of batak simalungun language at the wedding ceremony, 2.describe the grammatical meaning in the use of batak simalungun language at the wedding ceremony. This is qualitative research. Data collection techniques used in this study through the process of observation of written data with notes and applying interview methods for oral data. Oral sources come from speakers directly who the author hears in different contexts. Generally the language used by the speecher in that context is simalungun language. The context in which it is interpreted is the situation on various occasions for example; parties and informal conversations. Data analysis to see the meaning in the expression of speakers, the author also read the writing data that is books containing conversations simalungun language. The purpose of this method is to analyze the grammatical and lexical meanings of the expression batak simalungun at wedding ceremonies.

Keywords: Grammatical and Lexical Meanings, Simalungun
\end{abstract}

\section{PENDAHULUAN}

Bahasa Simalungun termasuk sebagai salah satu bahasa daerah di wilayah nusantara maupun Indonesia pada dasarnya masih eksis digunakan para penuturnya. Para penutur bahasa daerah simalungun tersebut baik yang masi kental mau pun yang sudah campuran di wilayah simalungun maupun kabupaten simalungun atau yang masi berdomisili.Bahasa Simalungun adalah bahasa daerah yang sudah dipakai oleh suku simalungun yang termasuk dalam salah satu suku Batak yang ada disumatera utara. Suku simalung merupakan suku yang terdapat di provinsi Sumatera Utara, pada dasarnya keaslian ini berada di daerah Kabupaten Simalungun. Namun berkembangnya kemajuan serta 
pesatnya tolak ukur ekonomi yang menyebabkan percampuran antar suku dikarenakan pekerjaan didaerah lain seperti Kabupaten Karo, Kabupaten Deliserdang, Kabupaten Serdang Berdagai, Kabupaten Asahan, serta mungkin sudah sampai pada Provinsi-provinsi lainnya.

Ungkapan yang digunakan masyarakat Simalungun pada umumnya tidaklah berbeda dengan bahasa atau ungkapan yang digunakan masyarakat Simalungun yang sudah berada diluar zona asli Kabupaten Simalungun. Bentuk dari makna, maupun fungsi penggunaannya sama saja dengan apa yang telah digunakan di daerah Simalungun.Pemikiran tersebut sejalan dengan Semantik dan Pragmatik yang sebanarnya adalah dua cabang ilmu bahasa yang sama-sama menelaah makna-makna satuan lingual. Semantik adalah ilmu mengenai makna leksikal dan gramatikal atau biasa disebut makna yang internal. Sedangkan pragmatic ialah ilmu yang mempelajari mengenai makna dari satuan bahasa yang dipakai dalam komunikasi yaitu makna yang eksternal.

Berkenaan dengan makna ungkapan tersebut, Baharuddin (1997:87) berpendapat bahwa ungkapan bisa mengandung dua makna yaitu makna leksikal maupun gramatikal. Makna leksikal merupakan makna teridentifikasi satuan kebahasaan yang tidak bergabung dengan satuan lingual yang lain. Gramatikal sendiri maksudnya ialah makna yang diambil melalu penggabungan satuan lingual serta ciri yang ada di dalamnya. Menurut Chaer (2013:23) terdapat tiga proses yaitu reduplikasi, afiksasi serta komposisi. Oleh sebab itu makna leksikal ialah makna yang didapatkan melalui kata dasar atau kata utama berbeda dengan makna gramatikal yang dikutip dari kata melalui proses afiksasi maupun morfofonemik serta pemajemukan.

\section{METODE PENELITIAN}

Penelitian ini merupakan metode kualitatif, dimana proses melalui pengamatan data tertulis dengan catataan dan mengaplikasikan metode wawancara untuk data lisan. Tujuan dari metode ini adalah untuk menganalisi Makna Gramatikal dan Leksikal Pemakaian Ungkapan dalam Bahasa Batak Simalungun Pada Upacara pesta Adat Pernikahan, berikut langkah yang digunakan dalam penelitian ;

1. Pengumpulan Data
Penulis menerapkan metode pengamatan data tertulis dengan mencatat dan mengaplikasikan metode wawancara untuk data lisan. Dalam pembahasan ini penulis menggunakan data bahasa Simalungun yang diambil dari beberapa sumber secara lisan dan tulisan. Sumber lisan timbul berdasarkan analisi wawancara yang dicerna melalui ucapan narasumber, narasumber harus memiliki wawasan dalam budaya simalungun serta bahasa simalungun, kemudian narasumber yang dituju harus memahami bagaimana fungsi bahasa simalungun dan tata cara penggunaan dalam tiap situasi yang diperlukan seperti pada acara pesta pernikahan, keagamaan, dan kematian, baik formal dan nonformal.

\section{Analisis Data}

Untuk melihat ada tidaknya makna di dalam ungkapan penutur, penulis juga membaca data tulisan yaitu buku-buku yang berisi percakapan dalan bahasa Simlungun. Kemudian penulis menandai, memilah, dan menuliskannya dalam daftar dan kemudian menentukan apakah data tersebut memiliki makna tutur ungkapan tidak dengan melihat fungsi dan pembagiannya.

Data lisan didapatkan sesuai dengan tahap yang dilakukan yaitu dengan menanyakan narasumber secara langsung, narasumber yang dimaksud adalah datu atau penutur maupun orang yang paham mengenai budaya adat Simalungun dan paham mengenai bahasa Simalungun. Sementara itu, penulis juga sebagai keluarga penutur yang masih menggunakan bahasa Simalungun yang juga bertindak menjadi narasumber yaitu atok atau kakek penulis sendiri. Selanjutnya setelah dikelompokkan menurut fungsinya, setiap fungsi dikelompokkan lebih lanjut menurut pembagiannya. Pengungkapan yang dipakai hanya merupakan pengungkapan dalam kalimat ungkapan langsung yang didapatkan dalam percakapan atau dialog saat acara pesta adat pernikahan batak simalungun.

\section{HASIL PENELITIAN}

Makna Gramatikal dan Leksikal Pemakaian Ungkapan dalam Bahasa Batak Simalungun Pada Upacara Adat Pernikahan dapat dideskripsikan seperti yang tergambar pada uraian berikut;

Tabel 1. Upacara Adat Pernikahan Adat

\begin{tabular}{|l|l|l|}
\hline $\begin{array}{l}\text { Bahasa } \\
\text { Simalungun }\end{array}$ & Arti & Makna \\
\hline $\begin{array}{l}\text { "Horjahon ma } \\
\text { tonggomu, }\end{array}$ & $\begin{array}{l}\text { Artinya : } \\
\text { "Kerjakan lah }\end{array}$ & $\begin{array}{l}\text { Makna dari ungkapan } \\
\text { ini adalah untuk }\end{array}$ \\
\hline
\end{tabular}


Ismi Chairani Sartika Husnul, Imelda Amelia Gultom, Puteri Hermalia, Frinawaty Lestari Barus Makna Gramatikal dan Leksikal Ungkapan Bahasa Batak Simalungun pada Upacara Adat Pernikahan

\begin{tabular}{|c|c|c|c|c|c|}
\hline \multirow[t]{2}{*}{$\begin{array}{l}\text { Tpnggohon ma } \\
\text { horjamu" }\end{array}$} & \multirow[t]{2}{*}{$\begin{array}{l}\text { doamu, doakan } \\
\text { lah } \\
\text { perkerjaanmu. }\end{array}$} & \multirow[t]{2}{*}{$\begin{array}{l}\text { menasehati keluarga } \\
\text { yang harus selalu } \\
\text { berdoa dalam } \\
\text { keadaan apapun, apa } \\
\text { lagi pada saat bekerja, } \\
\text { berdoa lah untuk } \\
\text { pekerjaanmu agar } \\
\text { diberi kemudahan } \\
\text { dalam } \\
\text { menjalankannya, } \\
\text { serta dimurahkannya } \\
\text { rejeki dari pekerjaan } \\
\text { tersebut. }\end{array}$} & & & $\begin{array}{l}\text { dalam masalah apa } \\
\text { pun, karena sebesar } \\
\text { dan seberat apa pun } \\
\text { masalah akan dapat } \\
\text { diselesaikan dengan } \\
\text { baik-baik serta fikiran } \\
\text { yang tenang, jika kita } \\
\text { sabar menghadapinya } \\
\text { Tuhan akan } \\
\text { memberikan jalan } \\
\text { keluarnya. }\end{array}$ \\
\hline & & & \multirow{2}{*}{\begin{tabular}{lr}
\multicolumn{3}{c}{ "Hasuksesan } \\
roh humbani \\
diri r sendiri, \\
lang & humbani \\
halak & na \\
legan" &
\end{tabular}} & \multirow{2}{*}{$\begin{array}{l}\text { Artinya : } \\
\text { "Kesuksesan } \\
\text { datang dari diri } \\
\text { sendiri, bukan } \\
\text { dari diri orang } \\
\text { lain" }\end{array}$} & \multirow[b]{2}{*}{$\begin{array}{l}\text { Makna dari ungkapan } \\
\text { ini adalah sebuah } \\
\text { kesuksesan akan } \\
\text { diraih dengan kerja } \\
\text { keras serta usaha kita } \\
\text { sendiri, tidak pula } \\
\text { berasal dari usaha } \\
\text { orang lain, maka } \\
\text { harus lah bersungguh- } \\
\text { sungguh dalam } \\
\text { mecapai impian yang } \\
\text { kita inginkan. }\end{array}$} \\
\hline $\begin{array}{l}\text { "Perima } \\
\text { marsahap idilat } \\
\text { lobe bibir" }\end{array}$ & $\begin{array}{l}\text { Artinya } \\
\text { "Sebelum } \\
\text { berbicara, jilat } \\
\text { dulu bibirmu" }\end{array}$ & $\begin{array}{l}\text { Makna dari ungkapan } \\
\text { ini adalah untuk } \\
\text { menasehati agar } \\
\text { selalu menjaga } \\
\text { ucapan yang keluar } \\
\text { dari bibir, atau cerna } \\
\text { dulu serta pikirkan } \\
\text { dulu perkataanmu } \\
\text { sebelum berbicara, } \\
\text { agar tidak } \\
\text { menyinggung orang }\end{array}$ & & & \\
\hline & & lain. & $\begin{array}{l}\text { "Horas ma hita } \\
\text { sayur matua, }\end{array}$ & $\begin{array}{l}\text { Artinya : } \\
\text { "Semoga kita }\end{array}$ & $\begin{array}{l}\text { Makna dari ungkapan } \\
\text { ini adalah naehat agar }\end{array}$ \\
\hline \multirow[t]{2}{*}{$\begin{array}{l}\text { "Ulang } \\
\text { marpadan } \\
\text { anggo lang boi } \\
\text { i suhuni" }\end{array}$} & \multirow[t]{2}{*}{$\begin{array}{l}\text { Artinya } \\
\text { "Jangan berjanji } \\
\text { jika tidak dapat } \\
\text { ditepati" }\end{array}$} & \multirow{2}{*}{$\begin{array}{l}\text { Makna dari ungkapan } \\
\text { ini adalah untuk } \\
\text { menasehati agar tidak } \\
\text { mengumbar janji } \\
\text { yang belum tentu } \\
\text { dapat kita lakukan, } \\
\text { karena janji adalah } \\
\text { hutang, sehingga kita } \\
\text { dapat mengecewakan } \\
\text { orang lain dengan } \\
\text { sesuatu yang kita } \\
\text { janjikan. }\end{array}$} & $\begin{array}{l}\text { itumpak- } \\
\text { tumbak } \\
\text { naibatanta" }\end{array}$ & $\begin{array}{l}\text { umur panjang, } \\
\text { serta diberkati } \\
\text { Tuhan" }\end{array}$ & $\begin{array}{l}\text { dalam berkeluarga } \\
\text { selalu berdoalah } \\
\text { kepada Tuhan, agar } \\
\text { kita diberikan umur } \\
\text { panjang serta } \\
\text { diberkahin hidupnya. }\end{array}$ \\
\hline & & & $\begin{array}{l}\text { "Hujape hita } \\
\text { malalang, sai } \\
\text { dapot-dapotan" }\end{array}$ & $\begin{array}{l}\text { Artinya : } \\
\text { "Kemanapun } \\
\text { kita melangkah, } \\
\text { mudah-mudahan } \\
\text { jumpa tujuan" }\end{array}$ & $\begin{array}{l}\text { Makna dari ungkapan } \\
\text { ini adalah } \\
\text { memberikan doa } \\
\text { kepada pengantin } \\
\text { agar mereka dapat } \\
\text { hidup bahagia, serta }\end{array}$ \\
\hline \multirow[t]{2}{*}{$\begin{array}{l}\text { "Marhata-hata } \\
\text { nalang tongon } \\
\text { mambaen } \\
\text { bahat } \\
\text { paruttolon" }\end{array}$} & \multirow[t]{2}{*}{$\begin{array}{l}\text { Artinya : } \\
\text { "Berbicara yang } \\
\text { tidak benar } \\
\text { membuat banyak } \\
\text { masalah" }\end{array}$} & \multirow{2}{*}{\begin{tabular}{lr}
\multicolumn{3}{l}{ Makna dari ungkapan } \\
ini adalah untuk \\
menasehati agar tidak \\
terlalu banyak \\
berbicara, dan \\
berbicaralah dengan \\
kenyataan yang \\
sebenarnya, jangan \\
berbohong dengan \\
orang lain, itu hanya \\
akan menyebabkan \\
sebuah masalah atas \\
ketidak jujuran jika \\
kebohongan itu \\
diketahui.
\end{tabular}} & & & $\begin{array}{l}\text { setiap langkah yang } \\
\text { mereka jalani akan } \\
\text { mendapat tujuan yang } \\
\text { baik. }\end{array}$ \\
\hline & & & $\begin{array}{l}\text { "Ulang bei sai } \\
\text { marbadai, sai } \\
\text { roh ma uhur } \\
\text { damai" }\end{array}$ & $\begin{array}{l}\text { Artinya : } \\
\text { "Janganlah } \\
\text { selalu } \\
\text { bertengkar, } \\
\text { mudah-mudahan } \\
\text { datang hati yang } \\
\text { damai" }\end{array}$ & $\begin{array}{l}\text { Makna dari ungkapan } \\
\text { ini adalah } \\
\text { memberikan nasehat } \\
\text { agar tidak bertengkar } \\
\text { dalam berumah } \\
\text { tangga, dan selalu } \\
\text { diberikan kedamaian } \\
\text { dalam berkeluarga, } \\
\text { binalah rumah } \\
\text { tanggamu dengan } \\
\text { baik agar keluargamu }\end{array}$ \\
\hline \multirow{2}{*}{$\begin{array}{l}\text { "Padan lang } \\
\text { boi i lupahon, } \\
\text { sumpah lang } \\
\text { boi i langgar" }\end{array}$} & \multirow{2}{*}{$\begin{array}{l}\text { Artinya : "Janji } \\
\text { tidak bisah } \\
\text { dilupakan, } \\
\text { sumpah tidak } \\
\text { bisa dilanggar" }\end{array}$} & \multirow[b]{2}{*}{$\begin{array}{l}\text { Makna dari ungkapan } \\
\text { ini adalah untuk } \\
\text { menasehati dalam } \\
\text { pernikahan agar } \\
\text { paham atas janji dan } \\
\text { sumpah mereka, janji } \\
\text { merupakn sebuah } \\
\text { kesepakatan yang } \\
\text { harus kita pegang } \\
\text { dalam kehidupan, } \\
\text { sumpah merupakan } \\
\text { perjanjian kita } \\
\text { lakukan dengan } \\
\text { sungguh-sungguh } \\
\text { serta terhadap } \\
\text { kebesaran Tuhan. }\end{array}$} & & & $\begin{array}{l}\text { disertai dengan } \\
\text { kedamaian. }\end{array}$ \\
\hline & & & $\begin{array}{l}\text { "Anggo } \\
\text { domma } \\
\text { marrumah } \\
\text { tangga, ulang } \\
\text { maadong hata } \\
\text { mandok } \\
\text { sirang" }\end{array}$ & $\begin{array}{l}\text { Artinya : "Jika } \\
\text { sudah berumah } \\
\text { tanggah, jangan } \\
\text { ada lagi } \\
\text { mengatakan } \\
\text { untuk berpisah" }\end{array}$ & $\begin{array}{l}\text { Makna dari ungkapan } \\
\text { ini adalah jika sudah } \\
\text { berkeluarga jangan } \\
\text { pernah mengucapkan } \\
\text { kata perpisahan, } \\
\text { karna perpisahan } \\
\text { adalah sebuah } \\
\text { larangan dari Tuhan, } \\
\text { binalah rumah } \\
\text { tanggamu dengan } \\
\text { baik, jangan sampai } \\
\text { ada masalah, apalagi } \\
\text { sampai ada } \\
\text { perpisahan. }\end{array}$ \\
\hline $\begin{array}{l}\text { Lang dong } \\
\text { paruttolon } \\
\text { nalang boi i } \\
\text { saloseihon }\end{array}$ & $\begin{array}{l}\text { Artinya : "Tidak } \\
\text { ada masalah } \\
\text { yang tidak bisa } \\
\text { diselesaikan" }\end{array}$ & $\begin{array}{l}\text { Makna dari ungkapan } \\
\text { ini adalah untuk } \\
\text { menasehati sepasang } \\
\text { suami istri baru agar } \\
\text { tetap menjaga } \\
\text { keluarga mereka }\end{array}$ & $\begin{array}{l}\text { "Aha pe lang } \\
\text { na hurang, } \\
\text { anggo } \\
\text { marhasoman }\end{array}$ & $\begin{array}{l}\text { Artinya : } \\
\text { "Apapun yang } \\
\text { kurang, tetaplah } \\
\text { mengingat }\end{array}$ & $\begin{array}{l}\text { Makna dari ungkapan } \\
\text { ini adalah nasehat } \\
\text { agar sebuah keluarga } \\
\text { jika saling memiliki } \\
\text { kekurangan, atau }\end{array}$ \\
\hline
\end{tabular}




\begin{tabular}{|c|c|c|}
\hline Tuhan" & Tuhan" & $\begin{array}{l}\text { kesulitan jangan } \\
\text { pernah saling } \\
\text { menyalahkan, tetap } \\
\text { lah menerimanya dan } \\
\text { selalu berserah diri } \\
\text { kepada Tuhan karena } \\
\text { dia selalu } \\
\text { memberikan yang } \\
\text { terbaik pada umatnya. }\end{array}$ \\
\hline $\begin{array}{l}\text { "Anggo } \\
\text { domma } \\
\text { harosuh, ulang } \\
\text { isumengi, lang } \\
\text { ibadai" }\end{array}$ & $\begin{array}{l}\text { Artinya : "jika } \\
\text { sudah suka, } \\
\text { jangan lagi } \\
\text { dibohongi, dan } \\
\text { dimarahi” }\end{array}$ & $\begin{array}{l}\text { Makna dari ungkapan } \\
\text { ini adalah nasehat } \\
\text { pada pasangan laki- } \\
\text { laki dan perempuan } \\
\text { atau pengantin bahwa } \\
\text { mereka sudah saling } \\
\text { menyukai serta } \\
\text { mementukan pilihan } \\
\text { mereka, jadi jangan } \\
\text { lagi saling berbohong } \\
\text { satu sama lain, } \\
\text { perihan apapun itu, } \\
\text { karena kejujuran } \\
\text { dalam berkeluarga } \\
\text { sangat lah penting, } \\
\text { dan jangan memarahi } \\
\text { satu sama lain jika } \\
\text { berbuat salah, ajari } \\
\text { dia dengan baik serta } \\
\text { sayangi dia dengan } \\
\text { tulus. }\end{array}$ \\
\hline $\begin{array}{l}\text { "Anggo } \\
\text { domma itoktok } \\
\text { iporsan ma" }\end{array}$ & $\begin{array}{l}\text { Artinya : "Jika } \\
\text { sudah terbang } \\
\text { haruslah } \\
\text { dibawa" }\end{array}$ & $\begin{array}{l}\text { Makna dari ungkapan } \\
\text { ini adalah jika sudah } \\
\text { dibawa dalam } \\
\text { berkeluarga haruslah } \\
\text { mandiri, dengan tidak } \\
\text { lagi berada dirumah } \\
\text { orang tua, agar } \\
\text { mampu menjalani } \\
\text { rumah tangga dengan } \\
\text { baik, serta dapat } \\
\text { meraih kesuksesan. }\end{array}$ \\
\hline
\end{tabular}

\section{PEMBAHASAN}

Bentuk ungkapan dalam bahasa sangat beragam arti dan maknanya, namun dalam bahasa Indonesia bentuknya terdapat dalam dua bentuk yaitu kalimat tunggal dan kalimat majemuk. Seperti pada ungkapan "Jangan lihat rupa, perilaku lah yang engkau lihat". Dan jika didalam bahasa Simalungun berungkapan "Ulang martonggo rupa,parlaho do sitonggoran”. Yang didalamnya terdapat Makna yakni "Jika kita melihat seseorang jangan lihat tampangnya, karena wujud dengan rupa sangat jauh bertolak belakang, dimana wujud dapat berpenampilan baik serta bagus, namun rupa sangat lah jahat serta tidak berkepribadian baik, karena saat kita meliha seseorang tampak luar akan tertipu dengan sikap dan sifatnya, maka telitilah dalam menilai seseorang lihat dari keperibadian, sikap, dan perilaku dirinya terlebih dahulu". Ungkapan dalam bahasa Simalungun memiliki fungsi yang beragam dikarenakan bahasa yang bersanguktan dengan adat serta budaya. Setelah Datuk atau petutur dalam adat pernikahan menyampaikan ungkapan nasehat dilanjutkan dengan ritual adat berupa penyerahan ulos dari keluarga mempelai Laki-laki yang diserahkan kepada mempelai wanita, adat ini disebut dengan istilah "Ulos Pansamot". Kemudian sebaliknya keluarga perempuan memberikan ulos kepada pihak laki-laki yang disebut dengan istilah "Ulos Hela". Selanjutnya dilakukan tarian-tarian adat simalungun untuk merayakan acara adat pernikahan, yang dimana tarian ini diartika sebagai sebuah kebahagiaan seluruh keluarga atas pernikahan yang telah dilangsungkan.

\section{SIMPULAN}

Berdasarkan analisis makna leksikal dan makna gramatikal terhadap makna ungkapan dalam bahasa Simalungun dapat dimaknai berdasarkan makna gramatikal dan makna leksikal dari sebuah ungkapan. Makna yang terkandung dari sebuah ungkapan tersirat secara menyeluruh dari suatu kesatuan kata maupun kalimat pembangun sebuah ungkapan. Ungkapan dalam bahasa Simalungun memiliki fungsi sebagai sarana dalam pemberian nasehat dari seseorang ke oranglainnya. Bahasa Simalungun merupakan bahasa yang digunakan oleh orang-orang bersuku Simalungun atau juga salah satu subsuku dari suku Batak yang memang memiliki beberapa subsuku. Suku Simalungun terdapat di Provinsi Sumatera Utara, umumnya mereka berdiam di daerah Kabupaten Simalungun. Namun ada juga yang tinggal di daerah lain seperti Kabupaten Karo, Kabupaten Deliserdang, Kabupaten Serdang Bedagai, Kabupaten Asahan. Masyarakat Simalungun baik yang ada di kabupaten Simalungun maupun tidak, ungkapan yang digunakan biasanya tidak berbeda atau sama saja.

Dalam pesta pernikahan adat simalungun biasa penutur serta keluarga memberikan ucapan selamat serta nasehat yang akan menjadi bekal sepasang suami istri dalam menjalankan rumah tanggah, agar kehidupan-kehidupan yang dijalani terarah, tersusun, teratur, dan terbina dengan baik, setia sepanjang hidup dengan pasangannya mampu melewati tantangan perkaran didalam rumah tangga.

\section{SARAN}

Untuk melestarikan budaya leluhur yang ditinggalkan melalui bahasa-bahasa daerah, kita seharunya dapat menggunakannya dengan baik serta memanfaatkannya dengan 
Ismi Chairani Sartika Husnul, Imelda Amelia Gultom, Puteri Hermalia, Frinawaty Lestari Barus Makna Gramatikal dan Leksikal Ungkapan Bahasa Batak Simalungun pada Upacara Adat Pernikahan

benar, pergunakan sesuai dengan kebutuhan serta tatabahasa yang baik.

DAFTAR PUSTAKA

Baharuddin dkk. 1997. Lembaga

(peribahasa) bahasa

simalungun. Jakarta:

depertemen pendidikan dan

kebudayaan.

Purba, Baharuddin (2007). Penerapan

falsafah habonaron do bona

sebagai dasar

pembangunan masyarakat

simalungun. Sahur Majalah

Kebudayaan dan

Pengembangunan

Simalungun Indonesia. 2:16

Purba, Anita (2015). Verba tindak tutur bahasa simalungun (simalungun's speech acts). Vol xiii, no. 1 (16 mei 2021)

Rahmat (2015). Makna leksikal dan makna gramatikal: ruwatan, sukerta, dan murkawala lexical meaning and grammatical meaning: ruwatan, sukerta, and murkawala. Vol 5, no. 2 (16 mei 2021)

Hasyim, Zubeirsyah M, Zainal Abidin, Nurhayati Lubis, dkk. 2001. Kamus bahasa simalungunindonesia. Jakarta: PT Penerbit dan Percetakan Balai Pusta. 